\title{
The Influence of Police Training Programmes on Police Officers Participation in Good Police - Community Relations in Uganda
}

\author{
Sseggiriinya Fredrick* \\ College of Education and External Studies, Makerere University \\ P.O. Box 7065, Kampala, Uganda \\ Ezati Betty. \\ College of Education and External Studies, Makerere University \\ P.O.Box 7065, Kampala. Uganda \\ Wafula Wycliff Scot. \\ College of Education and External Studies, Makerere University. \\ P.O. Box 7065, Kampala. Uganda
}

\begin{abstract}
This study sought to investigate the influence of police training programmes on police officers participation in good police- community relations in Uganda. The investigation was provoked by the reportedly deteriorating performance of police officers in areas of good police - community relations despite of government's effort to transform Uganda to a middle income country by 2040. The specific areas studied were the influence of police training on their participation in provision of services to the community, community communal activities and provision of customer care. The study took an interpretive philosophical paradigm and was under pined by the Social learning theory and the Expectancy theory of Motivation. Data was collected using questionnaires, interviews, Focused Group Discussions, participant observation and documentary analysis. A total of 412 police officers and 80 non police officers participated in the study. Quantitative data was analyzed using SPSS by use of descriptive statistics, correlation analysis, Regression analysis and Analysis of Variance (ANOVA) while qualitative data was analyzed using thematic analysis by use of transcription, coding and themes development. The study findings showed a strong positive relationship between training programmes and participation in good police community relations, $(\mathrm{r}=0.654, \mathrm{p}=0.000, \mathrm{n}=412)$. It further showed that police training programmes are predictors of police officers participation in good police community relations promotions, $\mathrm{pv}<0.050(=0.000)$. The relationship is statistically significant at $95 \%$ confidence level. The researcher concluded that police training programmes influence police officers participation in good police- community relations in Uganda. Thus it was recommended that police management promote good police- community relations by allocating enough funds to standardize training and other activities related to good police - community relations promotions in Uganda.
\end{abstract}

Keywords: Police Training Programmes Good Police Community Relations Promotion.

DOI: $10.7176 / \mathrm{PPAR} / 9-10-04$

Publication date:October $31^{\text {st }} 2019$

\subsection{BACKGROUND TO THE STUDY}

In this study police training programmes means an inventory of activities, content and/or methods implemented to achieve police training objectives (acquiring/imparting knowledge, skills and/or competences), organized in a logical sequence over a specified period of time.

Police-community relations mean the attitude and behaviors between the police and the communities in relation to public relations, community service and community participation. The study was carried in Uganda between 2014-2019. Focus was on initial training programmes and targeted intakes of 2010 and 2014 in regard to whether the content, instructional, assessment strategies and instructional materials used enable them to participate in good police - community relations promotion. The study hypothesis was stated as: police training programmes influence police officers participation in good police - community relations promotion in Uganda. It was guided by the question. How do police training programmes influence police officers participation in good police community relations in Uganda?.

Police officers in Uganda are expected to through a thorough training and upon completion; they are expected to participate in good police - community relations promotion. ( The constitution of the republic of Uganda 1995 as amended, Police Act Cap 303 1994, Police Standing Orders 1984, Curriculum for the cadet officers initial training programme. 2015, Curriculum for the probationer police Constables. 2015, Uganda Police Force Training Policy . 2014, Uganda police force vision, mission, and core values, 2017). However upon graduation, their performance seem not in tandem with what they are taught, for example in 2017 the number of cases reported to police was 252,065 compared to 243988 cases in 2016 with common assaults, domestic violence, defilement, threatening violence, obtaining money by false pretense as the leading offences thereby reflecting an increase in 
the volume of crime by $3.3 \%$. Besides this , these graduates have been ranked in the third category with $7.8 \%$ of the total complaints received by the inspectorate of Government in form of bribery, extortion, mishandling of cases, abuse of office and delay of service delivery. Police Organization is among the slow government institutions in responding to the Inspectorate of Government Administrative Instructions (Inspectorate of Government Report. 2015 \& 2017). Failure to address these weaknesses will not only worsen police - community relations but will also hinder the achievement of Vision 2040 of a middle income country. Could the weaknesses in police performance be related to their training?.

\subsection{LITERATURE REVIEW AND METHODOLOGY}

Most of the reviewed literature revealed that police training programmes influence police officers participation in good police- community relations promotion (Mulis. 2009, Police Executive Research Forum.2015, Dowler. 2003, DeNita . 2017 \& Parker . 1956). However, most of the reviewed literature was from outside Uganda, carried out so many years ago and was not education based. This constituted geographical, time and methodological gaps necessitating for a similar study now, thus a justification for this study.

This study took an interpretive philosophical paradigm, a mixed research method and a survey research design. The study targeted 550 respondents, 450 respondents' from police officers and 100 from members of public. However, due to factors beyond the researcher only 492 responded 412 police officers and 80 from public. Sample sizes for known population sizes were determined by Krejcie and Morgan 1970 sample size determining table, Effect size and by using sample size calculator. For unknown population, sample sizes was delivered by computing the minimum sample size. Sampling techniques included Snowball, random, purposive and convenience sampling. Instruments used included questionnaires, interviews, observational checklist, and documentary analysis and focused group discussions. Validity was determined by using Content Validity Index while reliability was by Cronbach Alpha Coefficient.

Qualitative data analysis was by transcribing, coding and themes development. Quantitative data analysis was done by developing tables, computation of corresponding percentages from responses obtained, coding of key words and phrases in order to pinpoint common responses. Tallies and frequency counts were made and then percentages calculated. These are presented in tables to graphically represent all the categories and sub categories of the data got from the entire participants. Qualitative data trustworthiness was by ensuring credibility, transferability, dependability, conformability, keeping audit trails and reflexivity. Quality of Quantitative data was ensured by having a large sample size of $89.5 \%$, having a rigorous and involvement of various stake holders in the process of the instrument development, piloting the instrument, respondents completing the questionnaire in one session, and ensuring some ethical considerations such as respondents anonymity and being free to withdraw from the study if she or he felt unsecure. Mixed methods validity/ data legitimation was by employing the nine legitimation types advanced by Onwegbuzie and Johnson (2006) and these are sample integration, inside- outside, weakness minimization, sequential, conversation, paradigmatic mixing, commensurability, multiple validities, and political.

For easy data presentation, analysis and interpretation respondents were categorized into police officers and non-police officers. Strongly agree and agree were presented as agreed yet strongly disagree and disagree were presented as disagreed. Only majority, s views were presented, $60 \%$ and above was interpreted as enough and needed to be upheld while $59 \%$ and below was interpreted as insufficient and needed improvement. Results from interviews, documentary analysis, focused group discussion and observation sources were mixed up with the results from questionnaires and presented in this study. Expert opinion was sought from the two lead supervisors of the researcher, staff from Human resource development directorate of the Uganda Police Force. Some members from public were contacted for the same purpose. 
3.0 DATA PRESENTATION, ANALYSIS AND INTERPRETATION.

\begin{tabular}{|l|l|l|l|}
\hline Response category & $\begin{array}{l}\text { Targeted sample } \\
\text { size }\end{array}$ & Actual number of respondents & Response Rate \\
\hline Police training school dministrators & 8 & 8 & $100.0 \%$ \\
\hline Instructors & 125 & 111 & $88.8 \%$ \\
\hline Police graduates. & 312 & 268 & $85.9 \%$ \\
\hline District police leaders & 25 & 25 & $100.0 \%$ \\
\hline Members of public & 20 & 20 & $100.0 \%$ \\
\hline District leaders & 20 & 20 & $100.0 \%$ \\
\hline Community leaders & 20 & 20 & $100.0 \%$ \\
\hline Government agencies & 10 & 10 & $100.0 \%$ \\
\hline Non-government organisations & 10 & 10 & $100.0 \%$ \\
\hline Total & $\mathbf{5 5 0}$ & $\mathbf{4 9 2}$ & $\mathbf{8 9 . 5 \%}$ \\
\hline
\end{tabular}

Source: Primary data (2018).

Table 3. 1. Response rate.

Table 3. 1 shows that the response rate was $89.5 \%$ which shows that the study had a large response. This is a good response rate and offers a reasonable ground to make a case for any recommendations or observation. In line with this study, the researcher hopes that this was an adequate representation from police and members of public to draw reliable conclusions that can be generalised in line with the influence of police training programmes on police officers participation in good police - community relations in Uganda. In addition, this response rate shows the enthusiasm of the police officers and members of public on the influence of police training programmes on police officers participation in good police- community relations promotion in Uganda. This high response rate also reduces the unbiased estimates on the influence of police training programmes on police officers participation in good police - community relations promotion in Uganda.

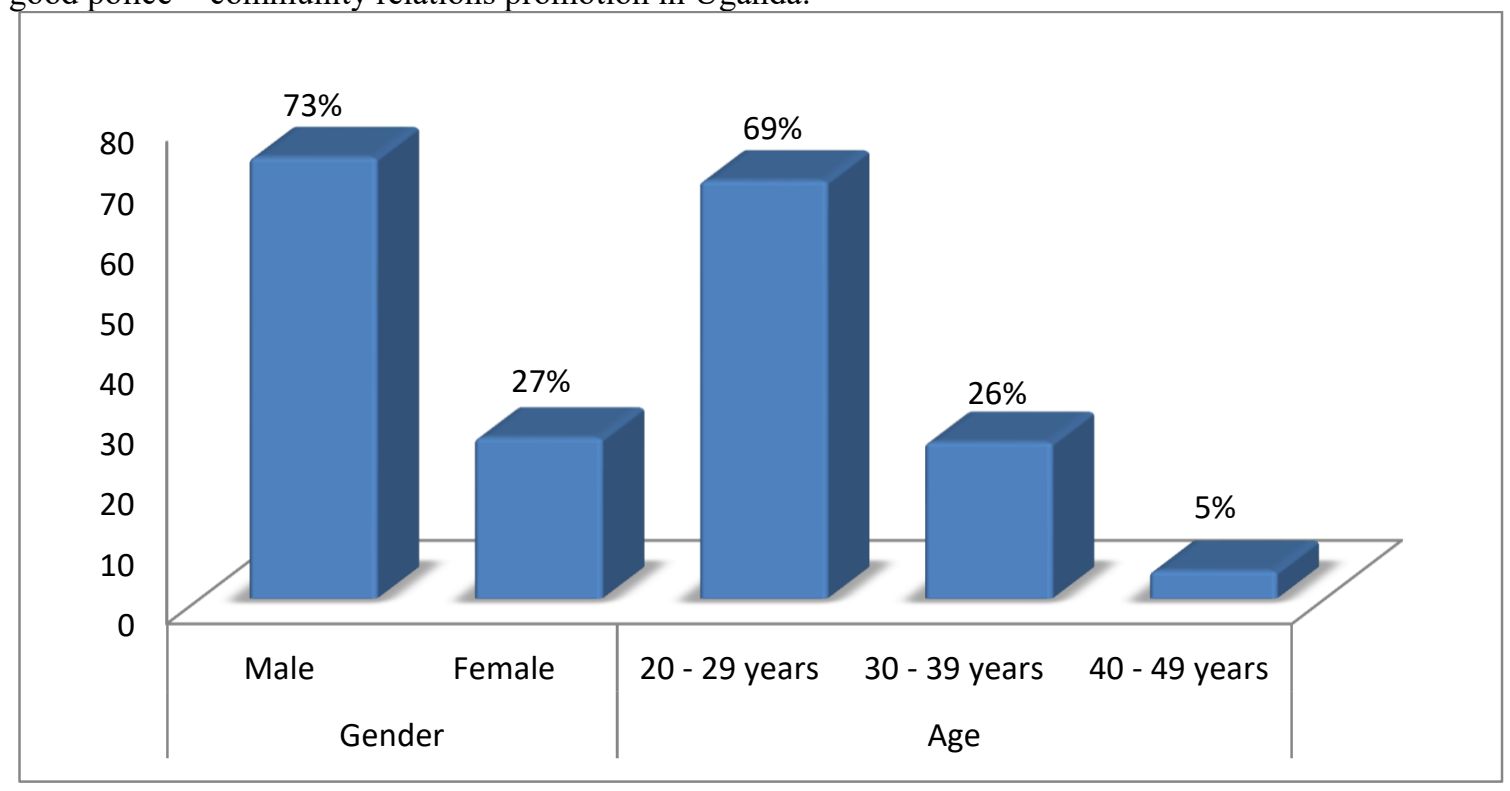

Figure 3. 1.Gender and age of the 412 police officers who answered the questionnaire

Figure 1 above shows that the majority of the police officers, 73 percent were male as compared to 27 percent that were female. In terms of age groups, the majority, 69 percent were aged $20-29$ years, whereas 26 percent were aged 30-39 years and five percent only were aged 40-49 years.

This confirms the UPF Strategic policing plan 2014/15-2020 as on October 2014 that there are more male police personnel than female police personnel in UPF (5958 females compared to 36752 male officers) and that majority of the personnel who participated in this study had gone through the same curriculum and are trainable. Secondary this is the age bracket where most Ugandans are facing challenges related to GPCRs as they are out of schools. 


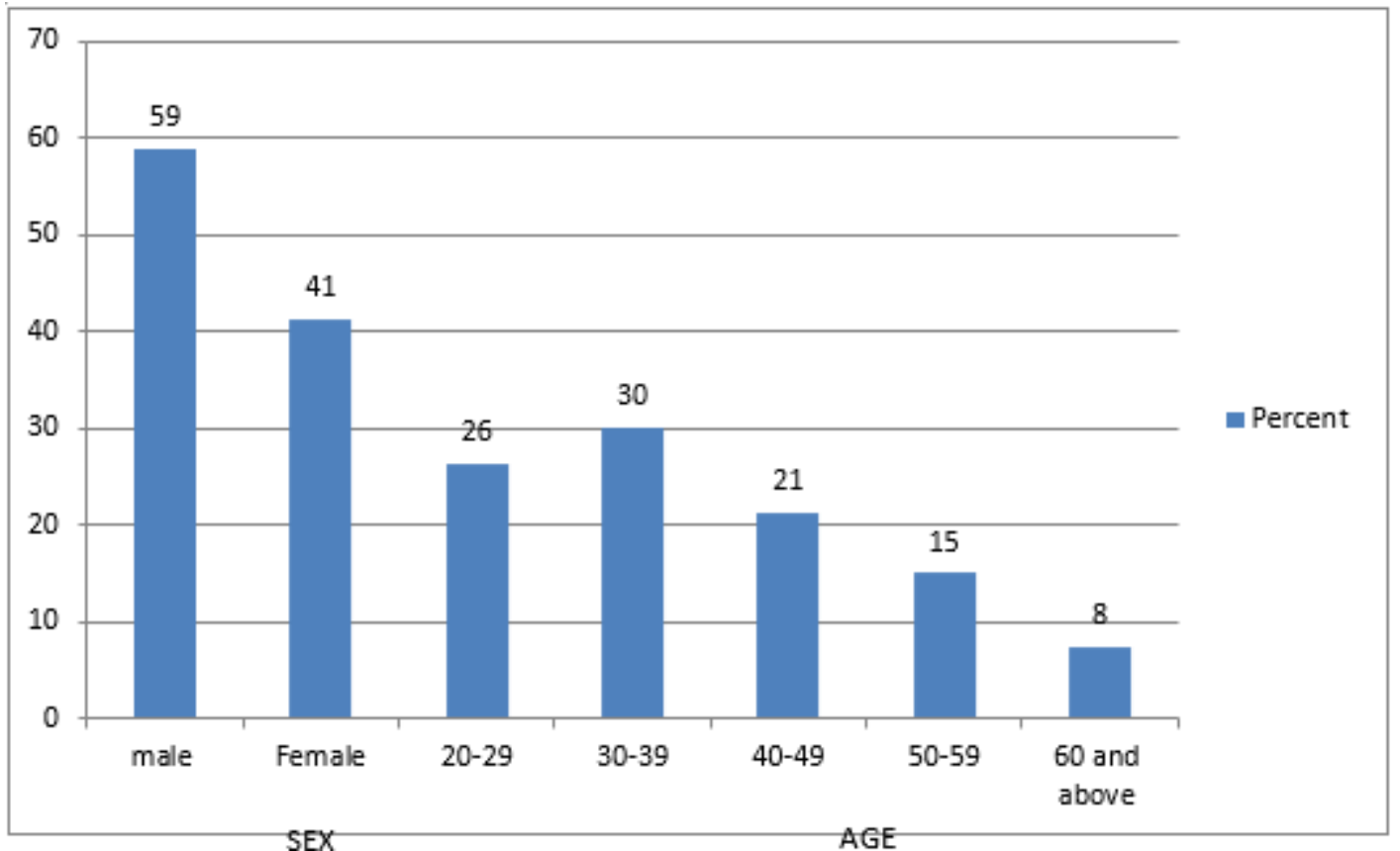

Figure 3. 2.Gender and age of the respondents from 80 non police officers.

According to the results in Figure 3. 2 , more than half $59 \%$ of the study respondents were male and $41 \%$ were female. Despite of the observed disparity in favor of men, the study was gender inclusive since data was obtained from both male and female members of the public. This therefore implies that the study findings can be generalized to represent views of both male and female members of the public about police participation in GPCRs in Uganda.

As indicated in the Figure 3. 2, the biggest proportion $30 \%$ of the study respondents were aged between 30 and 39 years of age, followed by $26 \%$ who were aged between $20-29$ years. $21 \%$ were between $40-49$ years. $15 \%$ of the respondents were aged between $50-59$ years and the last category of 60 years and above was represented by $8 \%$. This means that data were collected from mature people who understood well the study variables. Secondly, data was collected from different age categories of the members of public. This therefore implies that the study findings can be generalized to represent the views of the public at large about police participation in GPCRs in Uganda.

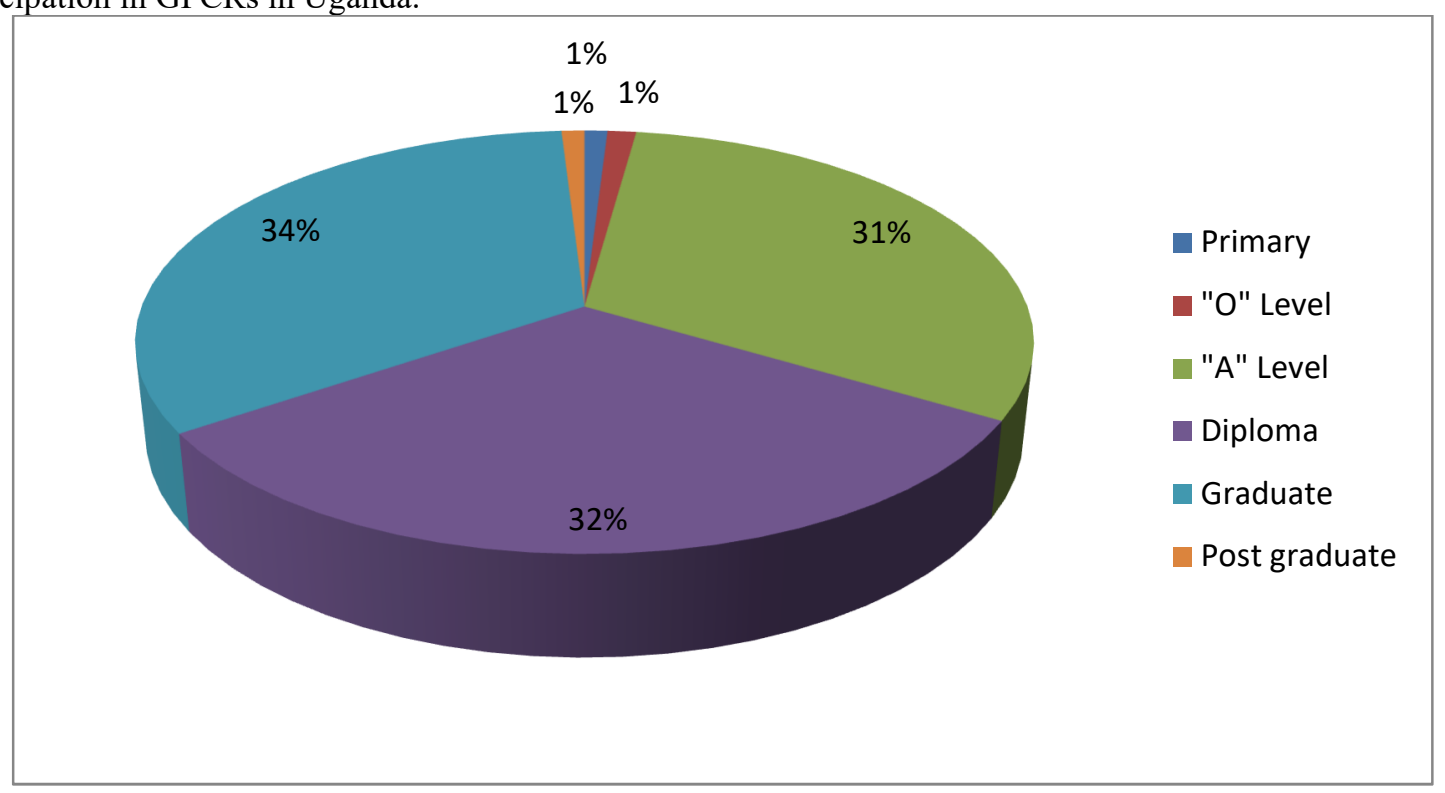

Figure 3. 3. Highest Academic Standards

Figure 3.3 shows that most of the police officers possessed "A" Level (31\%) (Higher school/advance level of education), Diploma (32\%) or Graduate (34\%) levels of education. Respondents with Primary, "O" Level (senior secondary education/ ordinary) or Post graduate levels of education were of negligible numbers. This means that the majority of respondents understood issues related to PTPs and police officers participation in 
GPCRs and are trainable as they had attained a reasonable level of education.

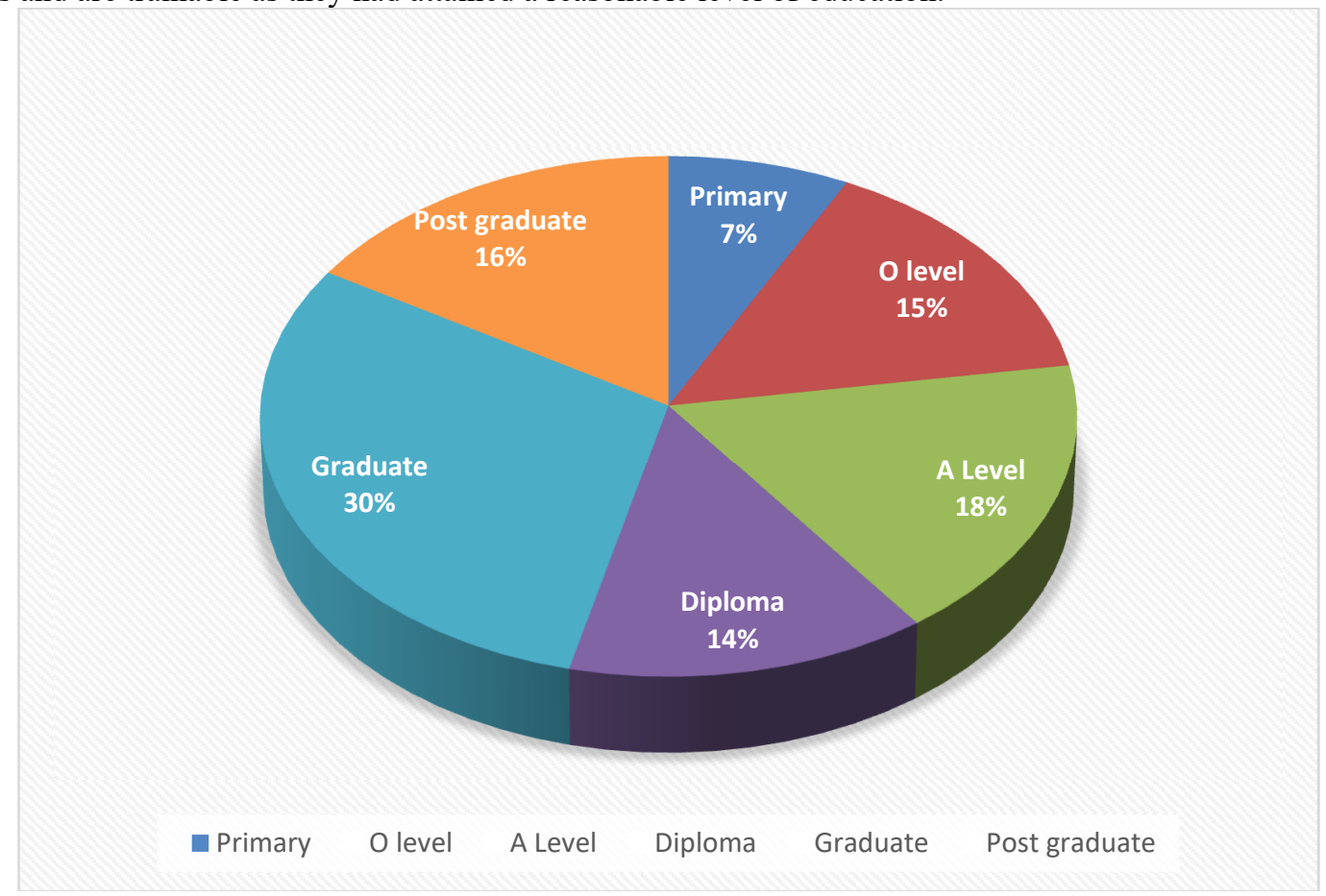

Figure 3. 4. Highest academic standards

Figure 3.4 indicate that most $30 \%$ of the study respondents were educated up to degree level, followed by $18 \%$ who were educated up to Advanced level, then by $16 \%$ who had attained post graduate qualification, then by $15 \%$ who had finished Ordinary level, then $14 \%$ who had attained ordinary diploma qualifications and lastly by $14 \%$ who were educated up to primary level. This shows that data was attained from respondents of different education categories. This implies that the views of the general public were well represented in the study.

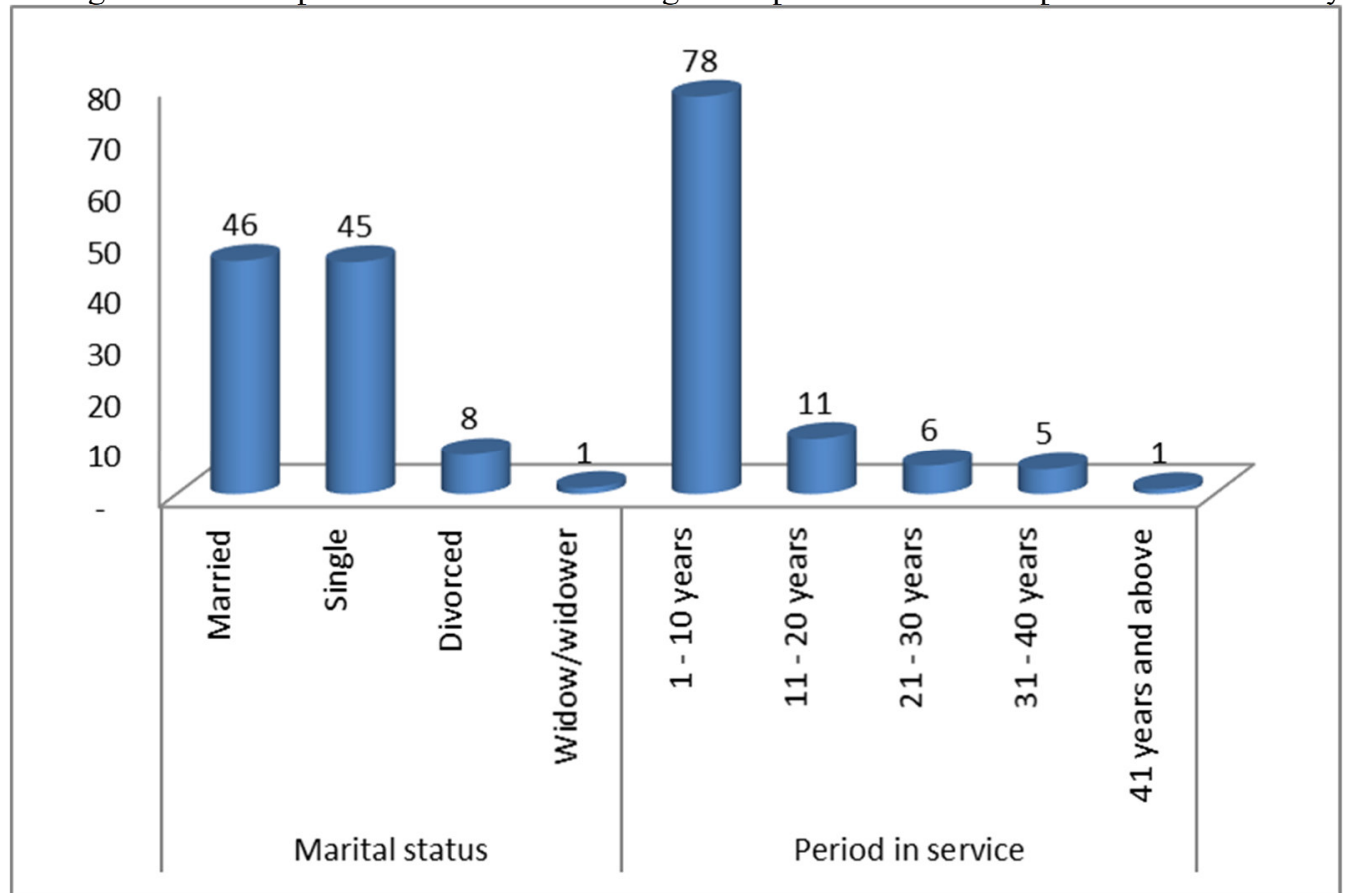

Figure 3. 5. Marital Status and Period in Service

Figure 3. 5 shows that police officers that were married (46 percent) were almost equal in number to those that were single (45\%), whereas the divorced constituted eight percent only and the windows/widowers comprised one percent only. In terms of period in service, the majority 78 percent had served between $1-10$ years, while 11 percent has served $11-12$ years and those that had served over 20 years were generally negligible in number. This means that majority of the respondents had experience to better apply personnel knowledge, understanding,skills, attitude and behavior on issues related to PTPs and police officers participation in GPCRs as they had gone 
through the same current curriculum.

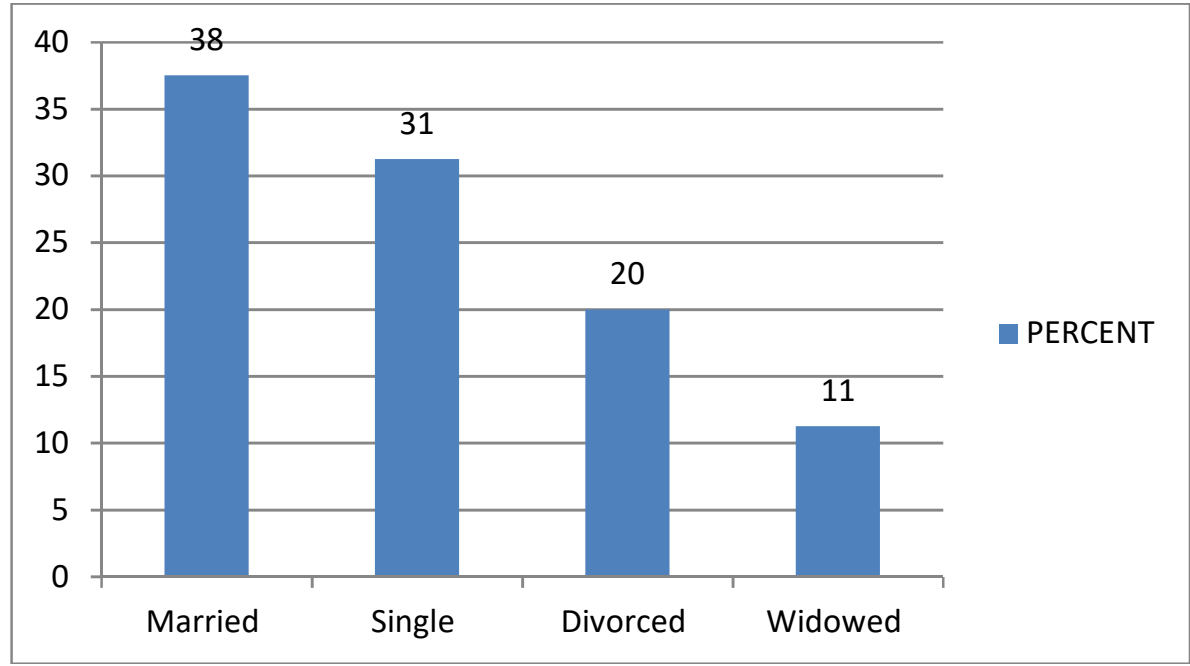

Figure 3. 6. Marital status of the respondents from 80 non-police officers

Findings in Figure 3.6 indicate that most $38 \%$ of the study respondents were married, $31 \%$ were single, $20 \%$ were either divorced or separated from their partners and lastly $11 \%$ were widowed. This shows that data was obtained from all the categories and this implies that it was free of marital bias and can be used to represent the views of the general public about police participation in GPCRs in Uganda.

\begin{tabular}{|c|c|c|c|c|c|}
\hline \multirow[t]{2}{*}{ Statements } & \multicolumn{5}{|c|}{ Percentage } \\
\hline & SA & $\mathbf{A}$ & D & SD & $\mathbf{N S}$ \\
\hline \multicolumn{6}{|l|}{ Training } \\
\hline Police officers in Uganda need more Training on Police-Community relations & 8 & 59 & 30 & 3 & 0 \\
\hline $\begin{array}{l}\text { Police Trainers cover police-Community relations promotion content in Uganda } \\
\text { adequately }\end{array}$ & 11 & 46 & 37 & 5 & 1 \\
\hline $\begin{array}{l}\text { Time allocated to cover police-community relations promotion content during } \\
\text { initial police training programmes in Uganda is enough }\end{array}$ & 13 & 52 & 27 & 6 & 2 \\
\hline $\begin{array}{l}\text { The assessment methods during initial training programme facilitated learning on } \\
\text { police-community relations. }\end{array}$ & 3 & 55 & 34 & 7 & 1 \\
\hline $\begin{array}{l}\text { The training methods during initial training programmes facilitated learning on } \\
\text { police-community relations. }\end{array}$ & 4 & 51 & 37 & 7 & 1 \\
\hline $\begin{array}{l}\text { The instructional strategies during initial training programmes facilitated learning } \\
\text { on police-community relation }\end{array}$ & 6 & 50 & 36 & 7 & 1 \\
\hline \multicolumn{6}{|l|}{ Performance } \\
\hline Police Officers in Uganda handle the Media Professionally & 7 & 55 & 28 & 9 & 1 \\
\hline Police officers in Uganda have good customer care & 7 & 52 & 32 & 9 & 0 \\
\hline Police has enough resources to promote police-Community relations in Uganda & 14 & 40 & 35 & 10 & 1 \\
\hline $\begin{array}{l}\text { Police officers have knowledge, understanding, skills , attitude and behavior to } \\
\text { handle journalists in Uganda }\end{array}$ & 45 & 8 & 44 & 2 & 1 \\
\hline
\end{tabular}

Source: Primary data (2018)

Table 3. 2. Police officers participation in good police - community relations promotion.

Table 3. 2 shows that when the police officers were asked whether Police officers in Uganda need more training on police-community relations, the majority, $67 \%$ agreed; $8 \%$ strongly agreed and $59 \%$ agreed. On the issue of whether Police trainers cover police-community relations promotion content in Uganda adequately, the majority, $57 \%$ agreed; $11 \%$ strongly agreed and $46 \%$ agreed.

Furthermore on whether time allocated to cover police-community relations promotion content during initial police training programmes in Uganda is enough, the majority, $65 \%$ agreed; $13 \%$ strongly agreed and $52 \%$ agreed.

When police officers were asked what police has done to promote good police- community relations, the following thematic themes were developed.

Police carries out community policing to update the community on crime prevention and other matters related to police on radios, televisions, newspapers other media, and platforms, Police has established departments to promote good police - community relations in Uganda. For example the department of community affairs and police public relations, it is one of the modules in the curricula at initial courses, Police punishes its errant members 
either criminally or disciplinary and Police partners with other government departments especially those under Justice, Law and Order Sector as well as with Non- government Organisations to promote crime prevention.

Also when police officers were asked what police should do to promote good police -community relations, the following themes were thematically generated. Police should continue with its community policing programmes and translate its publications into various local languages, Police should operationalize all its departments to the lowest police establishments and Police should review its curricula to focus on Problem Based Learning.

The majority of the respondents from public noted that police officers carried out meetings with their communities in villages and talked to them. These meetings were particularly on the local council level and respondents noted that it was the work of the local councils to ensure that the turn up of the people was appropriate and that people were organized. The police force also encouraged people to get involved in the community policing in which the police officers elected members whom they train for such work such village vigilante groups worked with the police. It was revealed that during the meetings the people are encouraged to ask questions to the police officers and through such interactions the communities come to realize the extent to which the willingness of the police force to provide security to the masses and this promotes police-community relations.

Furthermore, respondents noted that as a way of getting entrenched into communities, the police have established more posts in some communities as an attempt to extend services to the people. Many respondents believed that the establishment of such posts has beefed up security and peace in the communities. However, many people felt that the numbers of the police officers need to be increased in order to make community policing effective and more acceptable in the communities.

The majority of the respondents from public noted that police should work towards making community policing as more effective as possible. Respondents believed that community relations have a strong connection with community policing and community policing is premised on the level of community participation in enhancing safety and social order and in solving community-related crimes. Most respondents argued this level should be raised since the police cannot single-handedly carry out this task. Respondents noted that the police needs to engage public more in the fight against crimes. When community members work alongside the police in ensuring security, trust is established and this in turn promotes police acceptability.

In order to achieve such partnerships, respondents noted that the police must be better integrated into the community and strengthen its legitimacy through policing by consent and improving policing services to the public. Respondents noted that to achieve this, police must be visible and accessible to the public; know the public and the public knows them; respond to community needs; listen to community concerns; engage and mobilize the community; and be accountable for their activities and the outcome of these activities. On whether the assessment methods during initial training programme facilitated learning on police-community relations, majority, $58 \%$ agreed; $3 \%$ strongly agreed and 55\%agreed. . On the concern of whether the training methods during initial police training programmes facilitated learning on police-community relations, the majority, $55 \%$ agreed; $4 \%$ strongly agreed and 51\% agreed. Finally on the subject of whether the instructional strategies during initial training programmes facilitated learning on police-community relation, majority, $56 \%$ agreed; $6 \%$ strongly agreed and $50 \%$ agreed.

Table 3.2 shows that the majority of the police officers, $62 \%$ agreed that Police Officers in Uganda handle the media professionally; 7\% strongly agreed and 55\% agreed. On whether Police officers in Uganda have good customer care, the majority, $59 \%$ agreed; $7 \%$ strongly agreed and 52\% agreed. On whether Police has enough resources to promote police-community relations in Uganda, the majority, $54 \%$ agreed; $14 \%$ strongly agreed and $40 \%$ agreed. Table 3. 2 further shows that when the police officers were asked whether Police officers have knowledge, understanding, skills, attitude and behavior to handle journalists in Uganda, the majority, 53\% agreed; $8 \%$ strongly agreed and $45 \%$ agreed. Documentary analysis of the curricula books for cadets and probationers police constables( 2015) confirmed that good police- community relations is among the areas trained to police officers at initial courses. The whole initial training programme for cadet assistant superintendents of police has a grand total of 1204 lecture hours, 316 tutorial hours, 1830 practical hours, 3350 contact hours and 168 credit units. The same was also noted from the initial training programme for probationers' police constables training programme. The mode of assessment is by written examinations ( intermediate and final ) which is out of $50 \%$, classroom assignments / course work which is out of $15 \%$, practical assignments which is out of $30 \%$, peer rating which is out of $05 \%$. The pass mark is out of $50 \%$ and the methods of delivery are lecture, guided discussions, practical and simulations, demonstration, role play, multimedia and case studies.

List of reference materials, equipment, resources persons and facilitators ranks/ titles, names, formal education qualification, police/ related courses and years of experience are provided The analysis of these curriculum books revealed that all resource persons have attained formal education of not less than advanced certificate of education, have done several courses related to police and have experience of not less than five years in the force. The findings further revealed that the modules have course codes, course level, course description and the learning outcomes. 
Further documentary review revealed that Uganda Police Force has a Disciplinary Code of Conduct for all police officers and those who accept to perform duties in the force. The review of the Restructuring of the UPF by the Management services Department of the Ministry of public service and UPF revealed that there is a creation of new directorates, departments, and units which promote good police - community relations in Uganda. Other reviewed documents such as the police standing orders, police Act, the constitution among others confirmed police officers are supposed to promote good police - community relations while on duty.

Data from observation confirmed that police endeavors to promote good police -community relations in Uganda. For example police officers were observed participating into community activities like burial ceremonies, meeting, weddings and games and sports. They were observed while providing services to the community like medical and transport among others. In order to find out further what police should do to promote good police community relations in Uganda, an interview was held with a district leader and had this to say" some police officers tarnish the name of police and the country when they unprofessionally handle journalist, members of opposition, ask for bribes to do their work and when cited into criminal acts, so police management should continue punishing them criminally or disciplinary, police should operationalize all its structures up to the grassroots for easy service delivery and should increase its budget for activities related to promotion of good police - community relations such as community policing programmes". This district leader further said that "police should be provided with more human and non- human resources if good police - community relations is to be achieved in Uganda".

In a focused group discussion of 5 people from non - government organisations which deal with issues related to good police - community relations on what police should do to promote good police- community relations , members said that " police officers need more training on police community relations, police management should always punish errant officers, police officers be trained on sustainable development goals that deal with peace and security and police should emphasize scientific based means of training and policing such as electronic databases, driver and vehicle information, missing persons alerts, data on unresolved crimes, electronic speed radar guns, computer crime mapping, mobile laptop computers, portable crime scene technology, mobile crime cataloguing technologies, advanced GPS tracking systems, digital photos/ videos and radio frequencies to coordinate first responders and callers, sophisticated surveillance systems, face - to- face learning, hybrid and online learning environments among others if it is to get community satisfaction of its performance"

To find out further how police ensures good police - community relations, an interview was held with a police district leader and had this to say "police promotes good police-community relations through community policing, provision of good customer care, participation into community activities and provision of services to the community". In a focused group discussion with six police officers on the same, they said " The police do this through a number of ways; the force organizes community sports galas where they interact with the community, they open police posts within the communities, provide services like medical and transport to nearby communities, they also constantly keep the public in the know of what is going on in the country regarding law and order on televisions, radios and Newspapers, and hold meeting with other justice, law and order sector member as well as other stake holders on matters concerning law and order".

\begin{tabular}{|ll|l|l|}
\hline Study Variables & Training programmes & $\begin{array}{l}\text { Promotion of police public } \\
\text { relations }\end{array}$ \\
\hline Training programmes & $\begin{array}{l}\text { Pearson Correlation } \\
\text { Sig. (2-tailed) }\end{array}$ & 1 & $.654^{*}$ \\
& N & 412 & .000 \\
Pearson Correlation & $.654^{*}$ & 412 \\
Promotion of police- & Sig. (2-tailed) & 000 & 1 \\
community relations & $\mathrm{N}$ & 412 & \\
\end{tabular}

Table 3. 3 shows that there is a moderate positive relationship between training programmes and promotion of good police-community relations, $(\mathrm{r}=0.654, \mathrm{p}=0.000, \mathrm{n}=412)$. The relationship is statistically significant at $95 \%$ confidence level since p-value (Sig.) is less $0.050(=0.000)$. This means that improvements in Training programmes shall be related to improvements in promotion of police-community relations. Similarly decline in training programmes shall be related to decline in promotion of police- community relations.

Regression analysis was used to establish the influence of training programmes on police officers promotion of good-police community relations in Uganda and this was guided by the following hypothesis: 
Hypothesis: Police training programmes influence police officers participation in good police-community relations promotion.

The coefficient of determination ( $\mathrm{R}$ Square) one of the statistics under regression analysis is presented in table 3.4

\begin{tabular}{|l|l|l|}
\hline $\mathrm{R}$ & $\mathrm{R}$ Square & Adjusted R Square \\
\hline $0.654^{\mathrm{a}}$ & .428 & .426 \\
\hline
\end{tabular}

a. Predictors: (Constant), Training programmes

Table 4. Model Summary

Table 3.4 shows Pearson's correlation coefficient $(\mathrm{R}=0.654)$, Coefficient of determination or $\mathrm{R}$ Square of 0.428 and Adjusted R Square of 0.426 . An adjusted R Square of 0.426 means that Training programmes accounts for $42.6 \%$ of the variance in police officers promotion of police-community relations in Uganda. This means that when other factors are inserted in the regression model the magnitude of influence may change. Therefore training programmes with police -community relations content is one of the many factors that influence promotion of good police - community relations in Uganda.

To assess the overall significance of the regression model for training programmes and police officers' promotion of good police-community relations in Uganda, Analysis of Variance (ANOVA) and regression coefficients were generated and the results are presented in Table 3. 5.

\begin{tabular}{|l|l|l|l|l|l|l|}
\hline ANOVA & Df & F & Sig. & $\begin{array}{l}\text { Coefficients } \\
\text { Coefficient }\end{array}$ & Sign \\
\hline Rodel & 1 & 306.280 & 0.000 & 0.654 & 17.501 & .000 \\
\hline
\end{tabular}

a. Dependent Variable: Promotion of police -community relations

b. Predictors: (Constant), Training programmes

Table 3. 5. ANOVA and regression coefficients for training programmes and promotion of good police community relations in Uganda.

In determining whether a regression model is significant, the decision rule is that the calculated p-value (level of significance) for ANOVA must be less than or equal to 0.05. Since the calculated p-value of 0.000 is less than 0.05 , the regression model was found to be statistically significant $(\mathrm{F}=306.280, \mathrm{df}=1, \mathrm{p}<0.05(=0.000))$. This means that training programmes have a statistically significant influence on police officers promotion of policecommunity relations in Uganda.

Furthermore to establish whether training programmes are predictors of police officers promotion of good police-community relations and determine the magnitude to which training programmes influence police officers promotion of good police-community relations, Standardized Beta and t Coefficients were generated. For the magnitude to be significant the decision rule is that the $t$ value must not be close to 0 and the $p$-value must be less than or equal to 0.05 . Since the $t-$ value of 17.501 isn't close to 0 and $p$-value $<0.05(=0.000)$, the study confirmed that training programmes are predictors of police officers promotion of good police-community relations. A standardized Beta coefficient of 0.654 means; every 1 unit increase in training programmes will lead to an increase of 0.654 units of police officers promotion of good police-community relations. Thus, the hypothesis which had been stated as; Police training programmes influence police officers participation in good police - community relations in Uganda was accepted.

\subsection{CONCLUSION AND RECOMMENDATIONS.}

\subsection{Conclusion}

In conclusion, the findings revealed that training programmes with good police - community relations content have a moderate positive statistically significant relationship on police officers promotion of good policecommunity relations, that training programmes with good police-community relations content have a statistically significant positive influence on police officers participation in good police-community relations, and that training programmes with good police- community relations content are predicators of police officers participation in good police community relations. However some improvements in the content, instructional methodology, assessment, training environment and time should be done. As the study established that police training programmes provide insufficient scientific based policing knowledge and skill, provide inadequate communication and customer care abilities, they are underfunded, have inadequate curricula, lack adequate assessment and instructional methods and materials, and lack of operationalization of some departments to the lowest administrative police units among others.

\subsection{Recommendations}

This study recommends that Police management should allocate more funds and resources to training programmes to enhance standardization of training through curricula, syllabi and manuals development as well as monitoring and evaluation activities. Focus should be on the introduction of sign language, French and Arabic at the initial 
courses. This will enhance their job performance in the contemporary world. Police Management should also ensure that the newly created departments are operating up to the lowest police units

\section{REFFERENCES}

DeNita, R. S. S. (2017). Police and Citizens Perceptions of communitypolicing in Richmond, Virginia.

Dowler, K. (2003). Media Consumption and Public Attitudes toward Crime and Justice: The relationship between Fear of Crime, punitive Attitudes, and perceived police effectiveness. Department of Criminal Justice, California State University at Bakersfield.

Mulis, J. (2009). The impact of the media on public opinion of the police, California State University. Long Beach, Proquest . Dissertation Publishing 14772241.

Parker, W. A. (1956). In Johnson, D. \& Gregory J. R. (1971). Police-Community relations in the United States: A Review of Recent Literature and Projects. 62J. Crim. L. Criminology\& police sci.94 (1971).

Police Executive Research Forum, (2015). Why Police-Community Relationships are important.

Uganda police force (2006). Police Act cap 303. Government of Uganda. Kampala, Uganda.

Uganda Police Force (2015). Curriculum for the Cadet Officers initial training programme, leading to the award of a post graduate diploma in police, Associated Business Machinery, Kampala, Uganda.

Uganda Police Force (2015). Curriculum for the Probationers Police Constables initial training programme, leading to the award of a diploma in Police, Associated Business Machinery, Kampala, Uganda. 